\title{
Essential Oil Components of German chamomile Cultivated in Firoozabad, Iran
}

\author{
SHAHRAM AMIRI and SHAHRAM SHARAFZADEH* \\ Department of Agriculture, Firoozabad Branch, Islamic Azad University, Firoozabad, Iran. \\ *Corresponding author E-mail: shahramsharafzadeh@ hotmail.com
}

http://dx.doi.org/10.13005/ojc/300151

(Received: December 10, 2013; Accepted: January 29, 2014)

\begin{abstract}
Plant essential oils have medicinal properties. Flowers of German chamomile cultivated in Firoozabad, Iran were subjected to hydrodistillation. Isolated essential oil was analyzed by GC and GC-MS. Main oil constituents were $\alpha$-Bisabolol oxide A, Chamazulene, En-indicycloether, $\alpha$-Bisabolone oxide A, n-Octanal, $\alpha$-Bisabolol oxide B, 1,8-Cineole, $\alpha$-Terpineol and Germacrene D.
\end{abstract}

Key words: Chamazulene, Volatile oil, Bisabolol oxide, Medicinal plants, GC-MS.

\section{INTRODUCTION}

People around the world use between 50,000 to 80,000 flowering plants for medicinal purposes ${ }^{1}$.

Matricaria recutita L. (syn. M. chamomilla L., Chamomilla recutita L. Rauschert) known as true chamomile or German chamomile is from family Compositae. This plant has white ligulate flowers, smells pleasantly of chamomile and is annual, grows 10 to $80 \mathrm{~cm}$ in height ${ }^{2}$.

Phenolic compounds, glucosides and principal components of the essential oil extracted from the flowers like $\alpha$-bisabolol and its oxides and azulenes, including chamazulene are active substances of chamomile $e^{3-4}$.
The subject of this study was identification of essential oil components of German chamomile cultivated in Firoozabad, State of Fars, Iran.

\section{MATERIALS AND METHODS}

\section{Plant materials and experimental conditions}

This study was conducted on Firoozabad Branch (28 $35^{\prime} \mathrm{N}, 52^{\circ} 40^{\prime} \mathrm{E} ; 1327 \mathrm{~m}$ above sea level), Islamic Azad University, Firoozabad, State of Fars, Iran, on October (autumn), 2012. The pots were filled by a mixture contained $2 / 3$ soil and $1 / 3$ sand (v/v) which was amended by cow manure vermicompost. This mixture was tested before sowing and showed $\mathrm{PH}=7.79$, organic $\mathrm{C}=1.14 \%$, total $\mathrm{N}=0.1 \%$, available $\mathrm{P}=5.5 \mathrm{mg} / \mathrm{kg}$, available $\mathrm{K}=184 \mathrm{mg} / \mathrm{kg}$, $\mathrm{TNV}=52.5 \%$ and $\mathrm{EC}=0.7 \mathrm{ds} / \mathrm{m}$. Chamomile seeds were germinated in pots and thinned at 2-4 leaves stage to one plant per each pot. The experiment was 
carried out using three replications. Each replicate contained 14 pots. The flower heads were collected each 20 days during flowering (four times), and were dried at room temperature.

\section{Essential oil isolation}

Isolation of essential oils was performed using hydrodistillation of dried sample of flower heads using a Clevenger-type apparatus over 3 hours. The oils were dried over sodium sulphate.

\section{Gas chromatography (GC)}

Gas Chromatography analysis was performed on an Agilent technologist model (7890A) equipped with flame ionization detector and capillary column HP-5 (30 m × $0.32 \mathrm{~mm}, 0.25 \mu \mathrm{m}$ film thicknesses). The chromatographic conditions were as follows: The oven temperature increased from 60 to $210^{\circ} \mathrm{C}$ at a rate of $3^{\circ} \mathrm{C} / \mathrm{min}$ then 210 to 240 ${ }^{\circ} \mathrm{C}$ at a rate of $20^{\circ} \mathrm{C} / \mathrm{min}$. The injector and detector temperatures were 280 and $290^{\circ} \mathrm{C}$, respectively. $\mathrm{N}_{2}$ used as the carrier gas $(0.5 \mathrm{ml} / \mathrm{min})$.

Gas chromatography-mass spectrometry (GCMS)

Essential oil was also analysed by GCMS (Agilent Technologies-5975C-MS, 7890A-GC) equipped with a HP-5 capillary column (phenyl methyl siloxane (30 $\mathrm{m} \times 0.25 \mathrm{~mm}, 0.25 \mu \mathrm{m}$ film thickness) with $\mathrm{He}$ as the carrier gas and a split ratio of 1:50. The retention indices for all the components were determined according to the Van Den Doll method using n-alkanes as standard. The compounds were identified by comparison of retention indices (RRIAP-5) with those reported in the literature and by comparison of their mass spectra with the Wiley and mass finder 3 libraries or with the published mass spectra.

\section{RESULTS AND DISCUSSION}

Qualitative and quantitative analysis of essential oils have been shown in Table 1. Twenty nine components were identified in chamomile oil. The major components were $\alpha$-Bisabolol oxide A (17.14\%), Chamazulene (15.12\%), En-indicycloether (6.22\%), $\alpha$-Bisabolone oxide A (6.15\%), n-Octanal (6.00\%), $\alpha$-Bisabolol oxide B (5.17\%), 1,8Cineole (3.86\%), $\alpha$-Terpineol (3.11) and Germacrene D $(3.02 \%)$.
Presibella et al. (2006) analyzed commercial samples of Chamomilla recutita in Brazil and indicated that $\alpha$-Bisabolol oxide $A$ was $11.61-16.57 \%$ whereas in Egyptian sample was $46.55 \%{ }^{5}$.

Gamal El-Din and Abd El-Wahed (2005) in an Egyptian experiment revealed that $\alpha$-Bisabolol oxide $\mathrm{A}$ and Chamazulene were $57.81 \%$ and $11.78 \%$, respectively, in control chamomile plants ${ }^{6}$.

Table 1: Essential oil components of German chamomile cultivated in Firoozabad, Iran

\begin{tabular}{|c|c|c|c|}
\hline No & $\mathbf{R I}$ & Component name & $\%$ \\
\hline 1 & 935 & $\alpha$-Pinene & $0.10 \pm 0.00$ \\
\hline 2 & 947 & Camphene & $0.23 \pm 0.01$ \\
\hline 3 & 975 & Sabinene & $0.09 \pm 0.02$ \\
\hline 4 & 1003 & Yomogi alcohol & $0.15 \pm 0.01$ \\
\hline 5 & 1006 & n-Octanal & $6.00 \pm 0.02$ \\
\hline 6 & 1026 & p-Cymene & $0.59 \pm 0.04$ \\
\hline 7 & 1030 & Limonene & $0.52 \pm 0.03$ \\
\hline 8 & 1037 & 1,8-Cineole & $3.86 \pm 0.01$ \\
\hline 9 & 1047 & (E)- $\beta$-Ocimene & $0.18 \pm 0.01$ \\
\hline 10 & 1059 & $\gamma$-Terpinene & $0.38 \pm 0.02$ \\
\hline 11 & 1064 & Artemisia ketone & $0.14 \pm 0.00$ \\
\hline 12 & 1087 & Artemisia alcohol & $1.17 \pm 0.02$ \\
\hline 13 & 1104 & Linalool & $0.81 \pm 0.01$ \\
\hline 14 & 1107 & n-Nonanal & $0.54 \pm 0.04$ \\
\hline 15 & 1171 & Terpinene-4-ol & $0.55 \pm 0.00$ \\
\hline 16 & 1196 & $\alpha$-Terpineol & $3.11 \pm 0.02$ \\
\hline 17 & 1394 & $\beta$-Elemene & $0.30 \pm 0.02$ \\
\hline 18 & 1422 & (E)-Caryophyllene & $0.47 \pm 0.01$ \\
\hline 19 & 1458 & (E)- $\beta$-Farnesene & $0.31 \pm 0.02$ \\
\hline 20 & 1484 & Germacrene D & $3.02 \pm 0.01$ \\
\hline 21 & 1499 & Bicyclogermacrene & $0.07 \pm 0.00$ \\
\hline 22 & 1567 & (E)-Nerolidol & $0.10 \pm 0.02$ \\
\hline 23 & 1583 & Spathulenol & $0.20 \pm 0.04$ \\
\hline 24 & 1589 & Caryophyllene oxide & $0.10 \pm 0.42$ \\
\hline 25 & 1663 & $\alpha$-Bisabolol oxide B & $5.17 \pm 0.01$ \\
\hline 26 & 1692 & $\alpha$-Bisabolone oxide A & $6.15 \pm 0.02$ \\
\hline 27 & 1740 & Chamazulene & $15.12 \pm 0.01$ \\
\hline 28 & 1763 & $\alpha$-Bisabolol oxide A & $17.14 \pm 0.03$ \\
\hline 29 & 1888 & En-in-dicycloether & $6.22 \pm 0.03$ \\
\hline
\end{tabular}

$\mathrm{RI}$, retention index

All data are means of three replications \pm standard deviation 
SzQke et al. (2003) in a Hungarian study with wild and cultivated chamomile showed that Bisabolol oxide A varied from $0.42 \%$ to 36.27 in the essential oil of flowers and this range for Chamazulene was $5.23 \%$ to $24.50 \%^{7}$.

Orav et al. (2001) in Estonia reported that the main constituents of Chamomile were bisabolol oxide A (20-33\%) and B (8-12\%), bisabolon oxide $A$ (7-14\%), (E)- $\beta$-farnesene (4-13\%), $\alpha$-bisabolol (8-14\%), chamazulene (5-7\%), and enyn-dicycloether $(17-22 \%)^{8}$.

In conclusion, composition of the essential oils could be markedly affected by the geographical environment, places that plants is grown, physical and chemical characteristics of soil, plant age, oil isolation method, etc.

\section{REFERENCES}

1. N.Y.M. Naguib, Adv. Environ. Biol., 5: 394-400 (2011).

2. R. Franke, Plant Sources. In: Franke R, Schilcher $\mathrm{H}$ (Eds.) Chamomile, Industrial Profiles. CRC Press, USA, 274 (2005).

3. N.G. Hadaruga, D.I. Hadaruga, C. Tatu, A. Gruia, C. Costescu, A.X. Lupea, J. Agroalimentary Proc. Technol., 15: 201-210 (2009).

4. H. Zidane, F. Aouniti, M.L. Fauconnier and A. Elbachiri, Orient J. Chem., 29(4): 1319-1324
(2013).

5. M.M. Presibella, L.D.B. Villas-Bôas, K.M. da Silva Belletti, C.A. de Moraes Santos, A. M. Weffort-Santos, Brazilian Arch. Biol. Techno., 49(5): 717-724 (2006).

6. K.M. Gamal El-Din, M.S.A. Abd El-Wahed, Int. J. Agri. Biol., 7(3): 376-380 (2005).

7. É. SzQke, E. Máday, G. Marczal, É. Lemberkovics, Acta Hort., 597 (2003).

8. A. Orav, T. Kailas, K. Ivask, Proc. Estonian Acad. Sci. Chem., 50(1): 39-45 (2001). 